\title{
Analysis of Pedagogical Content Knowledge Studies in the Context of Mathematics Education in Turkey: A Meta-Synthesis Study*
}

\author{
Nurullah Şimşek ${ }^{1}$ \\ Cumhuriyet University
}

\author{
Nihat Boz ${ }^{2}$ \\ Gazi University
}

\begin{abstract}
Studies that explore pedagogical content knowledge (PCK) in the field of mathematics education date back to the turn of the century in Turkey. In recent years, studies on PCK have gained momentum. Master's theses and doctoral dissertations have been written on PCK. In this context, there is a need to analyze the studies on PCK in Turkey to discover the dominant trends and to determine the gaps in the field. Understanding the current situation is important and essential for researchers in this field. Thus, this study analyzes PCK studies in the field of mathematics education in Turkey by using the meta-synthesis approach. As part of this study, 56 studies, which include 24 dissertations, 27 articles, and five proceedings all published between 2004 and 2015, have been analyzed. These studies were analyzed thematically and methodologically. Analyses of these works revealed that most of the studies had concentrated on determining the existing PCK of teacher candidates and that the most extensively studied PCK components were knowledge about students and knowledge of teaching strategies and representations. In addition it was found that qualitative approach was dominant methodology of these studies and algebra was the mostly studied mathematical context.
\end{abstract}

\section{Keywords}

Mathematics education • Pedagogical content knowledge • Meta-synthesis

\footnotetext{
* A part of this study was presented orally at the 11th National Science and Mathematics Education Congress from September 11-14, 2014, in Adana, Turkey.

1 Correspondence to: Nurullah Şimșek, Department of Secondary School Science and Mathematics Education, Cumhuriyet University, Sivas 58140 Turkey. Email: nurullah4006@gmail.com

2 Department of Secondary School Science and Mathematics Education, Gazi University, Ankara 06500 Turkey. Email: boz@gazi.edu.tr

Citation: Şimşek, N., \& Boz, N. (2016). Analysis of pedagogical content knowledge studies in the context of mathematics education in Turkey: A meta-synthesis study. Educational Sciences: Theory \& Practice, 16, 799-826.
} 
Existing studies conducted on education have aimed to contribute to educational reforms by focusing mostly on students. Both in Turkey and throughout the world, further studies are required to analyze teachers in addition to students, particularly teachers' knowledge base needs further investigation. Educational research should not necessarily be associated only with those conducted by collecting data in the field. Meta-synthesis studies that offer general outlooks on previous studies are also required in the field of education. To address this gap in the literature, this article aims to analyze studies in Turkey that have investigated pedagogical content knowledge $(\mathrm{PCK})$ in the field of mathematics education.

The concept of pedagogical content knowledge was first introduced by Lee $\mathrm{S}$. Shulman at the annual meeting of the American Educational Research Association in 1985. Shulman (1986) argued that there was an imbalance between content knowledge and general pedagogical knowledge and that no relation had been established between these two types of knowledge; he described this deficiency as the missing paradigm. With an effort to eliminate this deficiency, Shulman (1987) defined PCK as the special combination of content knowledge and pedagogy. Shulman conceptualized PCK in two categories. The first category is the knowledge of teaching strategies and representations that suggest how to organize, represent, and adapt the subjects that are taught. The second category is the knowledge of students' subject understanding at different levels. These two components are the unique professional expertise of teachers who act as the bridge connecting content and pedagogical knowledge.

Despite the fact that Shulman's conceptualization of PCK is considered a cornerstone in the literature, he was later criticized by scholars working in this field. Depaepe, Verschaffel, and Kelchtermans (2013) collected the criticisms directed at Shulman's PCK model under five categories. The first was the lack of a theoretical and empirical basis for the presence of PCK as a separate category in the knowledge base of teachers. The second was related to his static view of PCK as a type of factual knowledge that could be acquired and applied independently from the classroom context. The third criticism arose from the concern of researchers about the possibility of theoretically and empirically distinguishing PCK from content knowledge. The fourth was that Shulman conceptualized PCK in a very narrow framework under two categories. The fifth one relied on the argument that PCK cannot be normative, as it can vary according to culture.

In accordance with the criticisms in the literature, several scholars from different subject areas restructured Shulman's PCK model in different ways in an attempt to clarify the borders between PCK and other types of knowledge. In this context, the first studies on PCK were conducted by Shulman's colleagues (Grossman, 1990; Marks, 1990). Grossman, one colleague of Shulman, expressed PCK, which Shulman had framed too narrowly, by widening it. Grossman (1990) divided PCK into four 
components: (a) knowledge of students' understanding, (b) knowledge of teaching strategies, (c) knowledge of teaching purposes, and (d) knowledge of curriculum. Grossman expanded Shulman's PCK model by adding knowledge of teaching strategies and knowledge of curriculum as separate components in PCK.

Marks (1990), another colleague of Shulman, divided PCK into four components in light of his empirical study's findings: (a) knowledge of subject matter, (b) knowledge of students' understanding, (d) knowledge of teaching media, such as materials, books, and so on, and (d) knowledge of teaching processes. Marks argued that these four components were not independent from each other but that they intensively interacted with each other. He advocated his argument, expressing that a mathematics teacher, when deciding whether or not the examples of mathematical operations in a course book are sufficient, reflects to a certain extent his/her knowledge of media for content education, knowledge of teaching processes, and knowledge of students' content comprehension. The empirical studies of Marks attempted to support Shulman's model of teacher knowledge that had been established on theoretical bases and assumptions. He attempted to eliminate the deficiency in the literature through his empirical findings.

Numerous studies were conducted after 1990 in order to conceptualize PCK in different subject areas (Ball, Thames, \& Phelps, 2008; Cochran, DeRuiter, \& King, 1993; Gess-Newsome, 1999; Hill, Ball, \& Schilling, 2008; Hill, Rowan, \& Ball, 2005; Magnusson, Krajcik, \& Borko, 1999; Park \& Oliver, 2008; van Driel, Verloop, $\&$ de Vos, 1998). These researchers attempted to conceptualize PCK through various components or approaches on the basis of Shulman's definition, as had Grossman and Marks. Among them, Cochran, DeRuiter, and King (1993) argued that the concept of knowledge did not have a dynamic structure and was also not in line with the structuralist approach; additionally, they rephrased pedagogic content knowledge as pedagogical content knowing and claimed that pedagogical content knowing has a dynamic nature that becomes more effective with each new experience gained by teachers. Cochran et al. (1993), different from other researchers, defined PCK (pedagogical content knowing) in their own terms under four components, expanding the frame of the concept: pedagogical knowledge, content knowledge, knowledge of students' characteristics, and knowledge of the learning environment.

Gess-Newsome (1999), a researcher who re-conceptualized PCK differently, explained the structure of knowledge that teachers should possess by revealing two fundamental structures: the integrative model and the transformative model. The integrative model encompasses the intersection of content, pedagogical, and contextual knowledge that are combined by the teacher during the course of teaching. As each component maintains its own character, PCK is not present. As for the transformative model, it expresses a new knowledge category encompassing the synthesis of these three knowledge categories. 
Content knowledge, pedagogical knowledge, and contextual knowledge are synthesized and transformed into PCK. The researcher referred to an analogy from chemistry in explaining the difference between these two models. When two substances are mixed, the outcome is a mixture or a compound. In the mixture, the substances come together without losing their chemical properties and can be separated by physical means. Similarly, categories of knowledge come together in the classroom, without losing their distinct features in the integrative model. However, in a compound, the substances lose their chemical properties and a totally new substance is formed. Similarly, in the transformative model, a new knowledge category, PCK is formed from its constituents as a new concept.

The most prominent studies on re-conceptualizing PCK in the field of mathematics education were conducted by Hill, Ball, and colleagues (Ball, Thames, \& Phelps, 2008; Hill, Ball, \& Schilling, 2008; Hill, Rowan, \& Ball, 2005). Taking Shulman's model of teacher knowledge as a reference, Hill, Ball, and colleagues developed a new and comprehensive model based on their empirical work results in the field of mathematics education. They called this new model the mathematical knowledge for teaching (MKT). This model is divided into two categories: content knowledge and PCK. The category of content knowledge consists of three different components: common content knowledge, specialized content knowledge, and knowledge of mathematical understanding. The PCK category includes three different components: content and student knowledge, content and teaching knowledge, and knowledge of the curriculum. MKT has three important features that distinguish it from other re-conceptualizations. The first is the development of the MKT model based on the results of completely empirical studies. The second is the model feature that simplifies the operation of MTK in order to render it measurable. The third is that the MKT revealed a positive relationship between student learning and teachers' PCK (Depaepe, Verschaffel, \& Kelchtermans, 2013).

As seen above, PCK does not have a definition or conceptualization that researchers agree upon. This lack of clarity on PCK in the literature results from the need to clearly identify the subject matter of research and the components that are revealed. Whether PCK has a structure specific to each subject (functions, trigonometry, etc.) or a more general structure applicable to each course (mathematics, science, etc.) is still a dilemma in the literature. The dynamic, complicated, and integral nature of PCK makes it difficult for scholars to reach a consensus on the subject. Various scholars have focused on different components in their re-conceptualizations (Van Driel \& Berry, 2010). Despite this general picture of PCK in the literature, PCK was stated to still offer the most widely used framework in studies on teacher education. PCK is present in the content of articles, dissertations, theses, and courses. Shulman has a very important place among referenced authors (Segall, 2004). For this reason, a systematic analysis of studies on PCK is important in terms of offering a general picture of the existing situation and presenting a guide for researchers who work or who will work in this field. 
Aydın and Boz (2012) offer an analysis of PCK studies in the field of science education in Turkey, mapping which parts have been studied and what types of deficiencies are in the field. Twenty-eight PCK studies in the field of science were analyzed in this study. During analysis, the following questions were answered for each study: Who were the participants of PCK? Which data collection tools were employed? What were the types of studies? In what fields and on which subject matters were the studies conducted? Had PCK been taken in the studies as a whole or was it on the basis of its components? What were the contexts of the studies? Had a comparison been made between the PCK of teacher candidates and experienced teachers? What was the timeline over which PCK data had been collected and analyzed? Lastly, what were the significant results of the studies? As a result of the analyses conducted under the above-mentioned criteria, the majority of studies was concluded to have been conducted with teacher candidates within a short period of time and that most of the studies were qualitative case studies. Furthermore, the studies were based on components and reported that teachers had had insufficient PCK, pedagogical knowledge (PK), and content knowledge.

In the field of mathematics education, Depaepe et al. (2013) systematically analyzed 60 articles in order to determine how PCK was studied and used in other countries and to determine its existing trends. The articles were selected from the databases of ERIC, Psyclnfo, and Web of Science. The researchers investigated how PCK had been conceptualized in those articles, in which countries and on which mathematics subjects PCK had been studied, what had been the applied methodologies, what perspectives had been used during the studies, and what had been the main results. This systematic analysis showed that Shulman's model had mostly been used in the articles; that the majority of the studies had been conducted in the United States; fractions, algebra, and functions had been the most studied subjects; and tests had been used in large-scale studies as data collection tools while classroom observations, interviews, and document analyses had been employed in small-scale studies. In addition, the researchers reported that PCK had been discussed from six different perspectives. These were: (a) the nature of teachers' PCK, (b) the relationship between PCK and content knowledge, (c) the relation between PCK and instructional practices, (d) the relationship between PCK and student learning, (e) the relation between PCK and personal features, and (f) the development of teachers' PCK. Researchers stated the primary results obtained through these perspectives in the articles as follows: There were gaps in the PCK of teachers, there was a strong relationship between PCK and content knowledge, PCK was necessary for effective teaching, there was a positive relationship between teachers' PCK and student learning, gender had no effect on PCK, providing teacher candidates with an education in their native language had a positive effect on PCK, teaching experience had a positive effect on PCK, and PCK differed among teachers from different countries.

Studies that have explored pedagogical content knowledge (PCK) in the field of mathematics education in Turkey date back to the turn of the century. In recent 
years, studies on PCK have gained momentum, and master's theses and doctoral dissertations have been written on PCK. In this context, analyzing studies that have been conducted on pedagogical content knowledge according to certain criteria is needed to identify any deficiencies or gaps. Determining the current situation is important and essential in providing guidance to the studies of those who plan to do research on this subject matter. In Turkey, no research has been found to have systematically analyzed PCK studies in the field of mathematics education, though one systematic analysis of PCK studies in the field of science education had been conducted (Aydin \& Boz, 2012). This study, which was designed to satisfy the abovementioned need, analyzed studies on pedagogical content knowledge in the field of mathematics education, as well as their trends, to identify the gaps and deficiencies.

This study seeks answers to the following research questions:

(1) What have been the general thematic features of PCK studies in the field of mathematics education in Turkey?

(a) What was the distribution of PCK studies in terms of the themes examined?

(b) Which components of PCK were studied more?

(c) Was PCK taken as a whole or as component wise in these studies?

(d) Which PCK components were studied together in the studies?

(e) Which mathematics subjects were preferred in the studies?

(f) What was the number of topic-specific studies?

(2) What have been the general methodological features of PCK studies in the field of mathematics education in Turkey?

(a) What were the types and designs of the studies?

(b) How was the sample profiled in the studies?

(c) Which data collection tools were used in the studies?

(d) Which studies used multiple data collection and which used single data collection methods?

(3) What have been the main results of PCK studies in the field of mathematics education in Turkey? 


\section{Method}

\section{Model of the Study}

This study is a meta-synthesis analysis where PCK studies in the field of mathematics education in Turkey have been systematically analyzed. A metasynthesis study (thematic content analysis) synthesizes and interprets studies that have been conducted on the same content by using themes or main templates through a critical perspective. Thus, meta-synthesis studies are expected to act as a guide for prospective research by analyzing studies conducted in a specific field using a qualitative approach to comparatively identify the similarities and differences between them (Çalık \& Sözbilir, 2014). This study is considered as a meta-synthesis study because it aims to systematically analyze theses, dissertations, articles, and proceedings on the pedagogical content knowledge in the field of mathematics education in Turkey to identify the trends of the studies and express the deficiencies and gaps therein.

\section{Data Collection}

The keywords used in the literature search were pedagogical content knowledge, knowledge of teaching mathematics, knowledge of subject matter education/teaching, and knowledge of pedagogic content matter. Google academic search engine, TUBITAK ULAKBIM Dergipark, EBSCOhost-ERIC, SPRINGER, and ISI Web of Science databases were scanned using these keywords. These databases were preferred because many national and international journals in the field of educational sciences are gathered in these databases. Furthermore, the webpage of YÖK National Thesis Center was also searched to access the relevant master's theses and doctoral dissertations. Studies included in this research were identified as a result of this search process. The reference lists from these studies were also searched to determine any missing relevant studies, which were then included in the research. The literature review consists of studies published up to November 2015.

\section{The Criteria for Data Inclusion to the Research}

Similar meta-synthesis studies (Aydin \& Boz, 2012; Depaepe et al., 2013; KaleliY1lmaz, 2015) were analyzed to determine the criteria to be employed in the selection of the studies to be included in the research. The following were used as the selection criteria in line with the criterion applied in these studies: (i) The study needs to have been conducted in the field of mathematics education in the theoretical framework of PCK, (ii) The data of the study needs to have been collected in Turkey or the Turkish Republic of Northern Cyprus, (iii) If the data of the study was published in different formats (thesis, article, or proceeding), the thesis format should be used; if not, the article format is preferred; if the article format is not available, its proceedings format should be 
included in the research, and (iv) inaccessible and partially accessible studies should not be included in the study.

Fifty-six studies in total met the above-mentioned criteria for inclusion in the study. Thirteen of these studies were doctoral dissertations, 11 were master's thesis, 27 were articles, and five were proceedings. The list of studies included here is available in the appendix. Within the scope of the determined criteria, some studies accessed as a result of the search were not analyzed. For example, the data from Kilıç's (2011) study was excluded from the research as the author had collected data from a state university in South America. Two studies (Işı1ksal \& Çakıroğlu, 2008, 2011) were excluded from the study as they were part of Işı1ksal's (2006) doctoral dissertation. In addition, because Türnüklü (2005) and Türnüklü and Yeşildere (2007) had used the same data collection tools and had the same objectives, only Türnüklü's (2005) study was analyzed. On the other hand, the study of Yeşildere-İmre and Akkoç (2010) was included in the analysis in its dissertation format as it was later published as an article in 2012.

\section{Analysis of Data}

Studies included in the research were first numbered from 1 to 56 . These numbers were used during the analysis and presentation of the data. Each study was then read in detail according to the research problems. The data obtained from each study according to the research problems were noted on paper and checked repeatedly. Categories were formed in the frame of the research problems. For example, two categories (teacher candidates and teachers) were determined as a result of the data analysis within the scope of the research question, "What is the sample profile in the PCK studies conducted in the field of mathematics education?" These two categories were then divided into three sub-categories: elementary school mathematics teacher, high school mathematics teacher, and classroom teacher. Other data obtained in the frame of the research problems were similarly analyzed and categorized. In addition, categories from similar meta-synthesis studies (Depaepe et al., 2013; Kaleli-Y1lmaz, 2015) were used during the formation of categories. For example, under the themes of analyzed studies, determination of PCK competences and analysis of PCK development were prepared by revising the determination of the categories of TPCK (technological pedagogical content knowledge) and analysis of TPCK development from the research of KaleliYilmaz (2015). On the other hand, the categories used by Depaepe et al. (2015) were used during the preparation of categories under the data collection tools applied in the studies related to PCK. The results of the analyzed studies were presented by analyzing them from the perspective of their themes. For example, the results obtained from studies conducted to determine PCK competence were analyzed together and presented under the title of results from the studies conducted with the aim of determining the PCK competence. 
The analyzed data have been presented to the reader as tables along with their frequencies. Later, each table was examined from a critical perspective to reveal the similarities, differences, and deficiencies.

\section{Validity and Reliability}

During the data analysis process, the related studies were examined in detail, in line with the research problems, by the first author; the data obtained was noted on paper, and categories were formed under each research problem. In order to ensure the reliability of the codings, the second author independently coded 14 randomly selected studies (25\% of all studies). Miles and Huberman's (1994) formula of [Reliability = (Agreement) / (Agreement + Disagreement)] was applied to determine the percentage of compromise between the authors. The reliability coefficient was calculated as 0.87 as a result of the analyses of the categories. The two authors agreed upon codings for which they could not agree before by analyzing them together once again. For example, the first author placed Study 6 under the category of analysis of the relationship between PCK and different variables according to its theme, while the second author placed the same study under the category of explanation of PCK structure. Later, when the two authors analyzed the study together, they decided this study should be placed under the category of explanation of the PCK structure. In addition, the data collection methods and analysis methods were explained in detail to ensure the reliability of the study.

During the analysis, each study that had been obtained was read and analyzed in accordance with the research problems. The data obtained from each study according to the research problems were noted on paper and controlled repeatedly. As such, it was attempted to minimize the effect of personal biases arising from long term interaction with data resources. Such approaches reinforce the validity of the study (Yıldırım \& Şimşek, 2008).

\section{Findings}

The findings of the analysis have been presented in three parts. In the first part, the general thematic features of PCK studies in the field of mathematics education have been expressed under three headings: (i) the themes examined in the analyzed studies, (ii) PCK components examined in the analyzed studies, and (iii) mathematics subjects preferred by the analyzed studies. In the second part, the general methodological features of the PCK studies in the field of mathematics education have been presented under three headings: (a) types and designs of the studies analyzed, (b) sample profiles of the analyzed studies, and (c) data collection tools employed in the analyzed studies. The third part expresses the important results of PCK studies in the field of mathematics education. 


\section{What Were the General Thematic Features of PCK Studies in the Field of Mat- hematics Education in Turkey?}

This section presents in detail the themes discussed in the analyzed PCK studies, the PCK components that were discussed, and the mathematics subjects that were preferred in the analyzed PCK studies.

The themes examined in the analyzed studies. When the research questions and aims in the PCK studies were analyzed, it was revealed that the studies organized around five themes: (a) determination of PCK competences, (b) examination of PCK development, (c) examination of the relationship between PCK and other variables, (d) scale/test development studies on PCK, and (e) explanation of the PCK structure (Table 1).

\begin{tabular}{|c|c|c|}
\hline $\begin{array}{l}\text { Table } 1 \\
\text { The Themes Discussed in the Analyzed Studies }\end{array}$ & & \\
\hline Theme & $f$ & Study Code \\
\hline Determination of PCK competences & 32 & $\begin{array}{l}1^{*}, 4^{*}, 5,10,12,13,14^{*}, 17,19,20,21, \\
22,26,27,32,34,35,36,38,40^{*}, 42,43, \\
44,45,47,48,50,52,53^{*}, 54,55^{*}, 56\end{array}$ \\
\hline Examination of PCK development & 11 & $8,9,11,25,28,30,31,33,41,46,51$ \\
\hline Examination of the relation between PCK and various variables & 8 & $1^{*}, 2,4^{*}, 7,14^{*}, 24,29,53^{*}, 55^{*}$ \\
\hline Scale/tests development studies on PCK & 4 & $23,37,39,40^{*}$ \\
\hline Explanation of PCK structure & 6 & $3,6,15,16,18,49$ \\
\hline
\end{tabular}

As can be seen in Table 1, 32 of the 56 studies had aimed to reveal the present condition of teachers or teacher candidates' PCK. Twenty-four of these studies $(1,4,5$, $10,13,17,19,20,26,27,32,34,35,36,38,40,42,43,44,47,50,52,54,56$ ) aimed to reveal the present PCK competence of teacher candidates. Six of the above 32 studies $(12,14,22,45,48,53)$ studied teachers, while two $(21,55)$ studied both teachers and teacher candidates. Unlike these studies, the Study 35 compared the current PCK competence of mathematics teacher candidates with classroom teacher candidates.

Eleven studies were designed to examine PCK development. In seven studies (8, $25,28,30,31,33,51)$ the effect of some content-enriched undergraduate courses on PCK were analyzed. In Study 9, the PCK development of teacher candidates throughout their undergraduate education was examined. Study 41 aimed to reveal the PCK development pattern during both undergraduate education and the active teaching period. In Study 11, the opinions of teacher candidates were taken on how sufficiently the courses improved PCK during their undergraduate education. Different from the others, Study 46 was conducted only with teachers. This study examined the effect of in-service training seminars on PCK.

There were eight studies that examined the relationship between PCK and various variables. Studies 1, 2, 4, 7, 24, and 29 examined the relation between PCK and 
mathematics knowledge. Studies 14, 53, and 55 aimed to reveal the relationship between teachers' professional experience and PCK.

Four studies were conducted in order to develop a scale or test regarding PCK. In Study 37, a scale was developed to determine the perceptions of teacher candidates regarding PCK. In Study 23, the structure of scenario-based interview questions used in the evaluation of teacher candidates and teachers' PCK, the way these questions were prepared, the way they were used, the types of data obtained through these questions were all discussed. Studies 39 and 40 aimed to develop a test whose validity and reliability were ensured in respect to the PCK measurements of teacher candidates.

Six of the analyzed studies aimed to describe the structure of PCK. Three of these studies $(15,16,49)$ were literature review studies attempting to theoretically describe PCK. Other studies $(3,6$, and 18) were empirically conducted to describe the structure of PCK.

PCK components examined in the analyzed studies. When the PCK components examined in the PCK studies were analyzed, eight different components were revealed: (a) knowledge of students, (b) knowledge of teaching strategies and representations, (c) knowledge of curriculum, (d) knowledge of measurement and evaluation, (e) contextual knowledge, (f) knowledge of mathematical language and symbols, (g) knowledge of misconceptions, and (h) beliefs (Table 2).

\begin{tabular}{|c|c|c|}
\hline \multicolumn{3}{|l|}{$\begin{array}{l}\text { Table } 2 \\
\text { PCK Components Examined in the Analyzed Studies }\end{array}$} \\
\hline PCK Component & $f$ & Study Code \\
\hline Knowledge of students (KS) & 36 & $\begin{array}{l}2,4,5,8,9,10,11,12,13,19,20,22,27, \\
28,30,32,33,35,36,37,38,39,40,41, \\
42,43,44,45,46,48,50,51,52,53,54,56\end{array}$ \\
\hline Knowledge of teaching strategies and representations (KTSR) & 36 & $\begin{array}{l}1,2,4,9,10,11,13,12,14,17,19,20,21 \\
24,28,30,31,33,34,35,36,37,38,39, \\
40,41,42,43,44,45,48,50,52,53,54,56\end{array}$ \\
\hline Knowledge of curriculum (KC) & 10 & $1,9,10,11,13,20,37,39,40,48$ \\
\hline Knowledge of measurement and evaluation (KME) & 3 & $10,25,48$ \\
\hline Contextual knowledge (CK) & 1 & 19 \\
\hline Knowledge of mathematical language and symbols (KMLS) & 1 & 37 \\
\hline Knowledge of misconceptions (KM) & 1 & 37 \\
\hline Beliefs & 1 & 31 \\
\hline
\end{tabular}

*Studies 15, 16, 23, and 49 were excluded from component-based analysis as they were literature review studies.

As can be seen in Table 2, researchers focused more on knowledge of students and of teaching strategies and representations. Ten analyzed studies examined the knowledge of curriculum. The components of contextual knowledge, beliefs, knowledge of misconceptions, and knowledge of mathematical language and symbols were examined only in study 37 and 31 . In some studies (3, 7, 18, 26, 29, 47, 55), PCK components were not clearly classified. These studies were organized under the concept of PCK as 
a whole without having stated PCK components. In the PCK studies, analysis of the components showed that 14 studies were about one PCK component, while 31 studies were related with more than one PCK component (Table 3).

\begin{tabular}{|c|c|c|}
\hline $\begin{array}{l}\text { Table } 3 \\
\text { The Condition of Including PCK }\end{array}$ & Components Together in the Analyze & ed Studies \\
\hline Type & PCK Components & $f$ Study Code \\
\hline & KS & $75,8,22,27,32,46,51$ \\
\hline 1he study focused on one PCK & KTSR & $66,14,17,21,24,34$ \\
\hline & KME & 125 \\
\hline & $\mathrm{KC}+\mathrm{KTSR}$ & 11 \\
\hline $\begin{array}{l}\text { The study focused on two PCK } \\
\text { components }\end{array}$ & $\mathrm{KS}+\mathrm{KTSR}$ & $192,4,12,28,30,33,35,36,38,41$, \\
\hline & Beliefs + KTSR & 131 \\
\hline The study focused on three PCK & $\mathrm{KS}+\mathrm{KTSR}+\mathrm{KC}$ & $69,11,13,20,39,40$ \\
\hline components & $\mathrm{KS}+\mathrm{KTSR}+\mathrm{CK}$ & 119 \\
\hline $\begin{array}{l}\text { The study focused on four PCK } \\
\text { components }\end{array}$ & $\mathrm{KS}+\mathrm{KTSR}+\mathrm{KC}+\mathrm{KME}$ & 210,48 \\
\hline $\begin{array}{l}\text { The study focused on five PCK } \\
\text { components }\end{array}$ & $\mathrm{KS}+\mathrm{KTSR}+\mathrm{KC}+\mathrm{KMLS}+\mathrm{KM}$ & 137 \\
\hline
\end{tabular}

Preferred mathematics subjects in the analyzed studies. An analysis of the PCK studies within the scope of mathematic subjects revealed that the studies were divided into two categories. The first consisted of studies conducted in the context of a specific subject of mathematics. The second included the studies conducted not in the context of a specific subject of mathematics. The first category consisted of 36 studies, while the second category consisted of 14 studies. Table 4 offers the subjects of mathematics explored in 36 studies conducted in the context of a specific subject of mathematics. As stated in the Turkish high school mathematics curriculum (grades 9-12), there are six learning areas in mathematics (MoNE, 2011, p. 13). These are logic, algebra, trigonometry, linear algebra, probability-statistics, and fundamental mathematics. However, the Turkish high school mathematics curriculum in 2013 gave three learning areas: numbers and algebra; geometry; data, counting and probability (MoNE, 2013a). In the Turkish secondary school mathematics curriculum (Grades 5-8) there are five learning areas: numbers and operations, algebra, geometry and measurement, data processing, and probability (MoNE, 2013b). As can be seen from these classifications and names of learning areas, there is no consensus among programs. As such, we decided to use fundamental mathematics, algebra, measurement, geometry, trigonometry, and statistics as learning areas. Furthermore, instead of learning areas, we used the term field. In this way we sought to give a more detailed and clear picture of subjects explored in PCK studies. The results of this categorization can be seen in Table 4 . 
Table 4

The Subjects of Mathematics Addressed in Topic-Specific PCK Studies

\begin{tabular}{|c|c|c|c|c|}
\hline Field & $f$ & Subject & $f$ & Study Code \\
\hline \multirow{3}{*}{ Fundamental Mathematics } & \multirow{3}{*}{6} & Limits and Continuity & 2 & 10,26 \\
\hline & & Definite Integral & 1 & 5 \\
\hline & & Derivative & 3 & $6,8,25$ \\
\hline \multirow{9}{*}{ Algebra } & \multirow{9}{*}{20} & Number Patterns & 2 & 17,28 \\
\hline & & Equations, Identities and Inequalities & 2 & $42 *, 54$ \\
\hline & & Fractions & 5 & $4,33,44,50,56$ \\
\hline & & Numbers & 2 & 32,41 \\
\hline & & $\mathrm{a} / 0, \mathrm{a}^{0}, 0 !$ & 1 & 14 \\
\hline & & Concept of Equality & 1 & 38 \\
\hline & & Operations & 3 & $18,34,36$ \\
\hline & & Functions & 3 & $12,19,42 *$ \\
\hline & & Variable & 1 & 1 \\
\hline Measurement & 3 & Length, Space and Volume & 3 & $27,39,48$ \\
\hline \multirow{4}{*}{ Geometry } & \multirow{4}{*}{7} & Solid Substances & 4 & $13,20,43,52$ \\
\hline & & Circle & 1 & $21^{*}$ \\
\hline & & Quadrilaterals & 1 & 45 \\
\hline & & Slope of a line & 1 & 55 \\
\hline Trigonometry & 1 & & 1 & $21 *$ \\
\hline Statistics & 1 & & 1 & 40 \\
\hline
\end{tabular}

Studies 15, 16, 23 and 49 were excluded from this analysis as they were literature review studies. Studies 11 and 37 were not conducted in the context of a specific subject as they aimed to identify the opinions and perception of teacher candidates in respect to PCK.

* Studies 21 and 42 were prepared in the context of two subjects.

As can be seen in Table 4, the most studied subject of mathematics was algebra in the PCK-related studies. Fractions, functions, and operations were the most preferred topics within algebra. Of the seven studies conducted on geometry, four were about solids, one was on circles, one was on squares, and one was on the slope of a line. Six studies were performed on fundamental mathematics in the context of the subjects of limit, continuity, derivative, and definite integral. The least preferred mathematics subject areas in the PCK studies were measurement, trigonometry, and statistics.

In each of the 14 studies that were not conducted on a single mathematical subject $(2,3$, $7,9,22,24,29,30,31,35,46,47,51,53)$, different mathematical subjects were examined together. In such studies, open-ended questions or scenarios were used as data collection tools. Each of these open-ended questions and scenarios were prepared on a different mathematics subject. In such studies, the subject of algebra was mostly preferred.

\section{The General Methodological Features of PCK Studies in the Field of Mathema- tics Education in Turkey}

This section explains in detail the types, designs, sample profiles, and data collection tools of the analyzed PCK studies. 
Types and designs of the analyzed studies. When PCK studies in the field of mathematics education were analyzed according to their types and designs, they were classified under the categories of qualitative method, quantitative method, literature review, mixed method, and unspecified. Table 5 represents the distribution of studies analyzed under these categories.

\begin{tabular}{|c|c|c|c|}
\hline \multicolumn{4}{|c|}{$\begin{array}{l}\text { Table } 5 \\
\text { The Types and Designs of the Analyzed Studies }\end{array}$} \\
\hline Study Type & Study Design & $f$ & Study Code \\
\hline \multirow{4}{*}{ Qualitative } & Case study & 26 & $\begin{array}{l}3,4,7,8,9,10,11,12,13,17,19,20,25,26, \\
27,28,32,43,44,45,46,48,50,52,54,56\end{array}$ \\
\hline & Action study & 1 & 30 \\
\hline & Grounded Theory & 1 & 38 \\
\hline & Unspecified & 6 & $22,29,34,36,21,53$ \\
\hline \multirow{3}{*}{ Quantitative } & Survey & 3 & $40,41,47$ \\
\hline & Experimental method & 1 & 33 \\
\hline & Comparative & 1 & 35 \\
\hline Literature Review & - & 4 & $15,16,23,49$ \\
\hline Mixed method & - & 4 & $1,14,39,42$ \\
\hline Unspecified & Unspecified & 9 & $2,5,6,18,24,31,37,51,55$ \\
\hline
\end{tabular}

As can be seen in Table 5, 34 out of 56 PCK studies in the field of mathematics education adopted the qualitative research approach. The most frequently used qualitative design in these studies was the case study. The action research and grounded theory were preferred in just one study. No study design was specified in six qualitative studies. Five studies were designed according to the quantitative research approach. Surveys were used in three of these studies, while each of the experimental methods and comparative methods was used in only one study. The mixed method, composed of both qualitative and quantitative approaches, was preferred in four studies. Another remarkable finding of the analyses on PCK studies according to their types and design was that the type and design were not stated in nine studies. On the other hand, four studies were organized as review studies regarding PCK.

Sample profiles of the analyzed studies. When the sample profiles of the studies regarding PCK were examined, two different participant profiles (teacher candidates and teachers) appeared. The sample profiles of the teacher candidates and teachers were divided into three categories: elementary school mathematics teacher, high school mathematics teacher, and classroom teacher. Table 6 presents the distribution of the studies analyzed under these categories. 


\begin{tabular}{|c|c|c|c|c|}
\hline \multicolumn{5}{|c|}{$\begin{array}{l}\text { Table } 6 \\
\text { Sample Profiles of the Analyzed Studies }\end{array}$} \\
\hline Sample Profile & $f$ & Type & $f$ & Study Code \\
\hline \multirow{3}{*}{$\begin{array}{l}\text { Teacher } \\
\text { candidate }\end{array}$} & \multirow{3}{*}{45} & Elementary school mathematics teacher & 21 & $\begin{array}{l}2,4,17,24^{*}, 27,28,31,32,35^{*} 37^{*}, 38, \\
39,40,41^{*}, 42,43,47,50,52,54,55^{*}\end{array}$ \\
\hline & & High school mathematics teacher & 14 & $\begin{array}{l}1,5,6,7,8,10,11,13,19,21,25,26, \\
37^{*}, 51\end{array}$ \\
\hline & & Classroom & 10 & $9,20,24 *, 30,33,34,35 *, 36,44,56$ \\
\hline \multirow{3}{*}{ Teacher } & \multirow{3}{*}{12} & Elementary school mathematics teacher & 7 & $3,29,41^{*}, 45,48,53,55^{*}$ \\
\hline & & High school mathematics teacher & 4 & $12,14,22,46$ \\
\hline & & Classroom & 1 & 18 \\
\hline
\end{tabular}

As Studies 15, 16, 23, and 49 were literature review studies, they were excluded from this analysis.

* In Studies 24, 35, 37, 41, and 55, two different sample profiles were studied at the same time.

As can be seen in Table 6, the sample profile was composed of teacher candidates in 45 of the PCK studies. Among the teacher candidates, elementary school mathematics teacher candidates were studied most frequently. The sample profile was composed of teachers in 12 studies. Among teachers, most of the data were collected from elementary school mathematics teachers. Among the studies in which the sample profile was composed of teachers, the duration of the professional experience in Studies 29 and 41 were not stated, while teachers with professional experience between 1 and 25 years formed the samples of the other studies.

Data collection tools in the analyzed studies. The analysis of the PCK studies in the field of mathematics education in terms of data collection tools revealed six categories (interview, questionnaire, document, observation, video recording, and test). Table 7 presents the distribution of the studies under these analyzed categories.

\begin{tabular}{|c|c|c|}
\hline \multicolumn{3}{|c|}{$\begin{array}{l}\text { Table } 7 \\
\text { Data Collection Tools in Analyzed Studies }\end{array}$} \\
\hline $\begin{array}{l}\text { Data Collection } \\
\text { Tools }\end{array}$ & $f$ & Study Code \\
\hline Interview & 36 & $\begin{array}{l}1,3,4,5,6,7,8,9,10,12,13,17,18,19,20,21,26,27,28,29,30,32,36,38,39 \\
40,42,43,44,45,46,48,51,53,54,55\end{array}$ \\
\hline Questionnaire & 25 & $\begin{array}{l}1,2,4,11,14,22,24,25,29,31,32,33,34,35,36,37,41,43,44,47,48,50,51 \\
52,56\end{array}$ \\
\hline Document & 23 & $3,2,5,6,7,8,9,10,13,19,20,21,26,27,28,30,31,38,45,46,48,51,55$ \\
\hline Observation & 15 & $3,9,10,17,19,20,21,26,27,30,31,45,46,48,54$ \\
\hline Video recording & 6 & $5,6,13,18,28,55$ \\
\hline Test & 8 & $6,7,9,10,19,39,42,47$ \\
\hline
\end{tabular}

As can be seen in Table 7, the interview was the most frequently used data collection tool in the studies. The interviews were generally conducted on scenarios that reflected the way students think $(1,3,4,9,10,12,13,19,20,27,29,32,38,53)$, course schedule as prepared by the participants $(5,6,7,8,9,21,26,28)$, or teaching practices of the participants $(9,13,17,18,21,26,28,30,45)$. Another frequently 
preferred data collection tool by the researchers was questionnaires. In 25 of the analyzed studies, questionnaires were used to collect data. The questionnaires were composed of scenarios reflecting a scene from the classroom environment or the thinking styles of students along with open-ended questions related to these scenarios $(1,2,4,14,22,24,29,34,35,36,41,43,44,48,50,52,56)$. In 23 studies, documents were used as a data collection tool. The researchers used course schedules $(5,6$, $7,8,10,13,19,21,26,27,28,30,31)$, observation notes $(3,9,10,19,26,27,30$, $31,45,48,55)$, instructional notes $(5,6,8,13,33)$, diaries $(38,46)$, and interview notes $(10,20,38)$ as documents. In 15 of the analyzed studies, observation was the preferred method for collecting data. In 12 of these studies, observations were video recorded, while the other three were not video recorded $(3,31,45)$. In six studies, the video recording method was used without observations. In these studies, the microteaching activities of teacher candidates or their teaching practices within the scope of the teaching practice course were recorded. Tests, which were less preferred by the researchers for collecting data, were prepared without item analysis to determine content knowledge in five studies $(6,7,9,10,19)$. In Studies 39, 40, and 42, tests were developed that proved their validity and reliability in terms of measuring PCK. In Study 47, item analyses were performed by adopting a 32-question performance test that included 23 mathematical knowledge test questions and nine pedagogical mathematical knowledge questions into Turkish within the scope of collecting data under the Teacher Education and Development Study in Mathematics (TEDS-M).

In 38 studies analyzed $(1-10,13,17-21,26-33,36,38-40,42-48,51,54,55)$, two or more data collection tools were used together. In these studies, data collection tools such as interviews, observations, and documents were generally used together. In 14 studies $(11,12,14,22,24,25,34,35,37,41,50,52,53,56)$, a single tool was used to collect data concerning PCK.

\section{Main Results Obtained by PCK Studies in the Field of Mathematics Education in Turkey}

The results obtained in the PCK studies are examined in detail and presented below under the headings composed of analyzed studies' themes.

\section{Main results obtained by studies conducted to determine PCK competences.}

The studies investigating PCK competences revealed that teachers have PCK gaps, and their competence was not at a sufficient level $(10,19,13,17,26,27,32,36$, $42,44,50,52,54,56)$. Another common result of these studies was that teacher candidates experienced difficulty in determining student misconceptions, and they were not capable of eliminating these misconceptions $(13,17,26,27,32,36,40$, $42,52,54,56)$. In the studies investigating teachers' PCK competences, the variety of approaches suggested by teachers concerning the teaching of the subject matter 
was reported to be few and far removed from conceptual perception, and these approaches tended to direct students toward rote learning $(12,14,53,48)$. While some studies reported that teachers with different experiences had difficulty in detecting and explaining student misconceptions and, moreover, some teachers even made mistakes similar to students $(22,53)$, other studies concluded that teachers were very successful in detecting student misconceptions and understood the cognitive reasons behind these misconceptions $(12,45)$. One study (35) compared the PCK competences of elementary school mathematics teacher candidates and classroom teacher candidates. Elementary school mathematics teacher candidates' PCK competence was determined to be higher than that of the classroom teachers.

Significant results obtained by the studies examining the development of PCK. Studies 8, 25, 28, 30, 31, 33, and 51, which had examined the development of PCK, stated that courses whose content was designed to reinforce teacher candidates had a positive effect on their development of PCK through reinforcement. Study 9 found that classroom teachers' PCK progressively improved during their university education. Similarly, Study 41 reported that mathematics teacher candidates' PCK had developed throughout their university education, and this development continued during their active teaching period. Study 46 underlined that the in-service seminars offered to teachers had contributed to their PCK development.

Significant results obtained by studies that examined the relation of PCK with various variables. The common result of most of the studies that had examined the relation between PCK and mathematics knowledge was the close relationship between PCK and mathematics knowledge $(1,2,4,24,29)$. The present knowledge of mathematics of teachers/teacher candidates was reported to affect their teaching approaches, as it had affected their ability to detect student misconceptions. These studies generally concluded that the content knowledge of teachers and teacher candidates was not sufficient for teaching mathematics, that their understanding of mathematics was at a procedural level, and that accordingly, their instructional explanations were also at a procedural level. Similarly, teachers and teacher candidates with poor content knowledge were reported to have difficulty understanding and analyzing students' mistakes. Even if few in number, teachers and teacher candidates with sufficient content knowledge were also stated to have a sufficient level of conceptual pedagogical content knowledge. Contrary to this, Study 7 indicated that there was an adverse relation between PCK and content knowledge. This study concluded that the teacher candidates with the strongest content knowledge had the weakest PCK, while the teacher candidates with the weakest content knowledge had the strongest PCK.

Studies 14 and 55 stated that there was a linear relationship between PCK and professional experience. Different from these studies, Study 53 reached the conclusion 
that no change was observed in the PCK of teachers as they gained professional experience over the years.

The results obtained in the studies about PCK scale/test development. Study 37, which focused on scale/test activities concerning PCK, developed a valid and reliable scale for detecting the perceptions of teacher candidates in respect to PCK. Study 39 developed a valid and reliable test to develop the PCK of elementary school mathematics teacher candidates in the fields of length, space, and volume. Similarly, Study 40 developed a valid and reliable test composed of multiple-choice and openended questions to measure the PCK of elementary school mathematics teacher candidates in the fields of length, space, and volume.

The results obtained in the studies explaining the structure of PCK. Study 3, which had aimed to determine the qualities of PCK, concluded that teachers' knowledge of basic mathematics and their beliefs concerning teaching and learning mathematics had a direct effect on their PCK. Study 6 underlined that previous education was very important in the development of PCK. On the other hand, Study 18 reported that education practices in PCK were affected by historical, political, institutional, and cultural factors.

\section{Discussion and Recommendations}

This section discusses the results of the meta-synthesis analysis of the 56 PCK studies in the field of mathematics education in Turkey. The results obtained were compared to those reported by Depaepe et al. (2013) in their international literature review study in the field of mathematics education, and the similarities and differences between their study and this one have been presented here. Additionally, recommendations have been made for future studies to be conducted in this field based on the results of this study.

Approximately $57 \%$ of the 56 PCK studies conducted in the field of mathematics education were performed with the purpose of determining PCK competences. An international literature review of PCK studies in the field of mathematics education revealed that approximately $26 \%$ of the analyzed studies had aimed to determine PCK competence (Depaepe et al., 2013). Also, the studies that aimed to reveal the current PCK level in Turkey outnumbered the studies in the international literature. Another interesting result is that the sample profile of PCK studies that aimed to determine PCK competence in Turkey were mostly composed of teacher candidates. In only eight studies was the sample composed of teachers, while 24 were composed of teacher candidates. Therefore it is stated in the literature that the number of studies that had examined the PCK competence of teacher candidates was sufficient. Furthermore a common result of these studies was that teacher candidates, lacking 
a conceptual basis, did not have a sufficient level of PCK competence. It is obvious that repeating the current analysis on different samples would not contribute to the literature. Working on treatment methods would offer a greater contribution after diagnosing the condition. In Turkey, what is required is not the determination of the present PCK competences of teachers, but the determination of activities and measures that are required to improve their competences.

Nineteen percent of the analyzed studies were organized so as to examine the development of PCK. However, Depaepe et al. (2013) stated in their literature review that approximately $55 \%$ of PCK studies were aimed towards examining the development of PCK. In Turkey, the number of studies that had aimed to reveal the present condition related to PCK was high, while the number of studies aimed at examining the development of PCK was limited. This was in contrast to what had been found in the international literature. In the international literature, the number of studies that had aimed to reveal the present condition related to PCK was lower than the number of studies that had aimed at examining the development of PCK. The sample profile of studies that had examined the development of PCK in Turkey heavily consisted of teacher candidates. Only two of the studies that examined the development of PCK concentrated on teachers. These results reveal the need for prospective studies in this field to concentrate more on teachers. The organization of in-service trainings, courses, and workshops are needed in order to enrich the present PCK of teachers.

The international literature review on studies in the field of mathematics education related to PCK reported that studies had examined the relation between PCK and mathematics knowledge, instructional practices, student learning, and personal features (age, gender, education level, race, and professional experience; Depaepe et al., 2013). In Turkey, studies had been conducted to analyze the relations among PCK, mathematics knowledge, and professional experience. In Turkey, further studies are required on the relationship between PCK and different variables like teaching practices, student learning, age, gender, type of high school that was graduated from, and education level (Master's degree, $\mathrm{PhD}$ ).

When the PCK components used in the studies were analyzed, the most frequently used PCK components in the field of mathematics education in Turkey were knowledge of students, knowledge of teaching strategies and representations. This result overlaps with the results obtained from the review of international PCK literature. The most frequently studied PCK components in the international literature are the knowledge of students, knowledge of teaching strategies and representations (Depaepe et al., 2013). The least studied PCK components in Turkey were contextual knowledge, beliefs, and knowledge of mathematical language and symbols. This is also in line with the international literature (Depaepe et al., 2013). These components should be 
included more frequently in future studies. On the other hand, 14 PCK studies in the field of mathematics education in Turkey had concentrated on one PCK component, while 31 PCK studies had concentrated on more than one PCK component. However, no study could be found that had examined all components of the PCK together or questioned the relationship between them.

In Turkey, the most frequently studied mathematics field in PCK studies has been algebra. Functions, operations, and numbers were the most preferred in the field of algebra. Trigonometry, probability, statistics, integrals, and geometry were the least preferred subjects in PCK studies. This result also shows similarities with the international literature (Depaepe et al., 2013). Fourteen analyzed PCK studies had not included any focus on mathematics subjects. However, as PCK has a topicspecific structure, there has been a consensus in the literature concerning the topicspecific study of PCK (Loughran et al., 2004; van Driel, Verloop, \& De Vos, 1998). Topic specific PCK studies would increase the level of the validity of the results.

An analysis of the research models applied in PCK studies in the field of mathematics education in Turkey represented the fact that most studies had been based on a qualitative research model. Either quantitative or both qualitative and quantitative approaches had been used in a few studies. Another intriguing result of the analysis is that some studies, though few in number, were conducted with a quantitative approach and on large samples (Studies 39, 40, 42). This is believed to be a reflection of foreign projects which had been conducted with a quantitative approach on large samples, namely Learning Mathematics for Teaching (LMT), Diagnostic Teacher Assessments in Mathematics and Science (DTAMS), and Cognitive Activation in the Classroom (COACTIV). In this context, it is necessary to conduct new PCK studies that use the quantitative approach on larger samples. On the other hand, because the research model makes up the infrastructure of a study, problem identification and hypothesis writing are not independent of the research model. Any mistake in the design of the research model can affect an entire study (Erkuş, 2013; Karadağ, 2010). Another striking result is that no research model or design had been stated in nine PCK studies, even though employing a suitable research model is very important for conducting research.

When the sample profiles were examined, approximately $80 \%$ of the studies worked with teacher candidates. Two primary reasons are believed to be behind these results. First, it is easier to access teacher candidates. Secondly, teachers may not be interested in such studies. For this reason, measures need to be taken by both researchers and relevant authorities so as to ensure that teachers are included in PCK studies. On the other hand, academicians were not present in the sample profile of the analyzed PCK studies. Undoubtedly, PCK studies on academicians would make a significant contribution to the literature. 
Interviews and documents were preferred more frequently in PCK studies in the field of mathematics education in Turkey. This is in accordance with the results obtained from the international literature review regarding PCK in the field of mathematics education (Depaepe et al., 2013). Due to the complicated nature of PCK, using different data collection tools together in PCK studies offers a clearer picture of PCK (Baxter \& Lederman, 1999). Therefore, different data collection tools were used together in 38 studies. In studies that used only one tool to collect data, the data had been presented more superficially. Another finding about data collection tools is that psychometric tests that evaluated PCK in large samples had been developed in recent years. In Esen's (2013) and Mercimek's (2013) doctoral dissertations and in Güler's (2014) master's thesis, they developed tests whose validity and reliability were tested for the purpose of evaluating PCK. The developments of such tests are required in different subjects of mathematics.

Another result of the PCK analysis in the field of mathematics education in Turkey is that there is a lack of common terminology. For example, PCK and its components were described differently in different studies. The expressions used for the concept of PCK in the analyzed studies are as follows: pedagogical subject matter knowledge $(2,8,10$, $12,14,15,17,20,21,29,33,35,36,38,41,43,44,45,51,52,53,54,56)$, knowledge of subject matter education $(3,9,16,23,27)$, pedagogical content knowledge (7, 4, $19,21,24,32,48)$, knowledge of subject matter teaching $(26,46,49)$, knowledge of mathematics teaching $(30,31)$, pedagogical mathematics knowledge (47), professional subject matter knowledge (55), and knowledge of teaching the subject matter $(34,42)$.

The term pedagogical content knowledge is used for PCK in the international literature. The use of these different terms in Turkey is an indicator that a common language has not yet been developed. Similarly, different terms were used for the components of PCK in different studies. To illustrate, the component of PCK concerning students was termed as follows in the analyzed PCK studies: knowledge about student difficulties (8), knowledge about the concepts that students experience difficulties with or misunderstand (10), knowledge of students' difficulties and misconceptions (27), knowledge about students (30, 42), knowledge about students' misconceptions and mistakes (32), knowledge of students and subject matter (36), subject matter and student knowledge (39), knowledge of understanding students (41), and knowledge of students' thoughts (46).

A similar situation has been seen in the international literature. The components of PCK concerning students were termed as follows in the PCK studies that had been analyzed: content knowledge and students (Ball, Thames, \& Phelps, 2008), knowledge of students' understanding (Grossman, 1990; Marks, 1990; Magnusson et al., 1999; Park \& Oliver, 2008), knowledge about mathematics related to student cognition (Krauss \& Blum, 2012), and knowledge of student learning and conceptions (Van Driel, et al., 1998). 
A common language has not yet been developed for PCK components in Turkey as it has been in the international literature. The lack of a common language in PCK literature in Turkey hinders communication between researchers (Aydin \& Boz, 2012). The development of a common language concerning PCK and PCK components is essential. Therefore, necessary actions should be taken by the concerned parties in order to develop a common language for PCK in Turkey.

\section{References}

Akkoç, H., \& Yeşildere, S. (2010, February). Investigating the development of pre-service elementary mathematics teachers' pedagogical content knowledge through a school practicum course, Paper presented at the World Conference on Educational Sciences, Bahçeşehir University, Istanbul, Turkey.

Aydın, S., \& Boz, Y. (2012). Review of studies related to pedagogical content knowledge in the context of science teacher education: The Turkish case, Educational Sciences: Theory \& Practice, 12, 479-505.

Ball, D. L., Thames, M. H., \& Phelps, G. (2008). Content knowledge for teaching: What makes it special? Journal of Teacher Education, 59(5), 389-407.

Baxter, J. A., \& Lederman, N. G. (1999). Assessment and content measurement of pedagogical content knowledge. In J. Gess-Newsome (Ed.), Examining pedagogical content knowledge: The construct and its implications for science education (pp. 147-162). Hingham, MA: Kluwer Academic Publishers.

Cochran, K. F., DeRuiter, J. A., \& King, R. A. (1993). Pedagogical content knowing: An integrative model for teacher preparation. Journal of Teacher Education, 44, 263-272.

Çalık, M., \& Sözbilir, M. (2014). İçerik analizinin parametreleri [Parameters of content analysis]. Ĕgitim ve Bilim, 39(174), 33-38.

Depaepe, F., Verschaffel, L., \& Kelchtermans, G. (2013). Pedagogical content knowledge: A systematic review of the way in which the concept has pervaded mathematics educational research. Teaching and Teacher Education, 34, 12-25.

Erkuş, A. (2013). Davranış Bilimleri İçin Bilimsel Araştırma Süreci [The scientific research process for behavioral sciences]. Ankara, Turkey: Seçkin Yayıncılık.

Gess-Newsome, J. (1999). Pedagogical content knowledge: An introduction and orientation to the nature, sources and development of pedagogical content knowledge for science teaching. In J. Gess-Newsome \& N. G. Lederman (Eds.), Examining pedagogical content knowledge: The construct and its implications for science education (pp. 3-17). Boston, MA: Kluwer.

Grossman, P. (1990). The making of a teacher. New York, NY: Teachers College Press.

Hill, H.C, Ball, D. L., \& Schilling, S. G. (2008). Unpacking pedagogical content knowledge: Conceptualizing and measuring teachers' topic-specific knowledge of students. Journal for Research in Mathematics Education, 39(4), 372-400.

Hill, H., C., Rowan, B., \& Ball, D. L. (2005). Effects of teachers' mathematical knowledge for teaching on student achievement. American Educational Research Journal, 42(2), 371-406.

Işıksal, M., \& Çakıroğlu, E. (2008). Öğretmen adaylarının kesirlerde bölmeye ilişkin öğrencilerin bilişsel süreçleri hakkındaki bilgileri [Pre-service teachers' knowledge about students' cognitive processes related to the division of fractions]. Hacettepe Üniversitesi Ĕ̈itim Fakültesi Dergisi, 35, 175-185. 
Işıksal, M., \& Çakıroğlu, E. (2011). The nature of prospective mathematics teachers' pedagogical content knowledge: the case of multiplication of fractions. Journal of Mathematics Teacher Education, 14(3), 213-230.

Kaleli-Y1lmaz, G. (2015). Analysis of technological pedagogical content knowledge studies in Turkey: A meta-synthesis study. Education and Science, 40(178), 103-122.

Karadağ, E. (2010). Eğitim bilimleri doktora tezlerinde kullanılan araştırma modelleri: Nitelik düzeyleri ve analitik hata tipleri [Research models used in educational sciences doctoral dissertations: Qualification levels and types of analytical errors]. Kuram ve Uygulamada Ĕ̈itim Yönetimi, 16(1), 49-71.

Kilıç, H. (2011). Pre-service high school mathematics teachers' knowledge of students. Turkish Online Journal of Qualitative Inquiry, 2(2), 17-35.

Krauss, S., \& Blum, W. (2012). The conceptualisation and measurement of pedagogical content knowledge, content knowledge in the COACTIV study, and their impact on student learning. Journal of Education Periodical of the Kenton Education Association, 56, 49-69.

Loughran, J., Mulhall, P., \& Berry, A. (2004). In search of pedagogical content knowledge in science: Developing ways of articulating and documenting professional practice. Journal of Research in Science Teaching, 41, 370-391.

Magnusson, S., Krajcik, J., \& Borko, H. (1999). Nature, sources and development of pedagogical content knowledge for science teaching. In J. Gess-Newsome \& N. G. Lederman (Eds.), Examining pedagogical content knowledge: The construct and its implications for science education (pp. 95-132). Boston, MA: Kluwer.

Marks, R. (1990). Pedagogical content knowledge: From a mathematical case to a modified conception. Journal of Teacher Education, 41, 3-11.

Miles, M. B., \& Huberman, A. M. (1994). An expanded source books qualitative data analysis (2nd ed., p. 352). London, UK: Sage.

Ministry of National Education. (2011). Ortaögretim matematik (9, 10, 11 ve 12. sinfflar) dersi ögretim programı [Mid-level mathematics curriculum (grades 9-12)]. Ankara, Turkey: Author.

Ministry of National Education. (2013a). Ortaögretim matematik (9, 10, 11 ve 12. sinıflar) dersi ögretim program [Mid-level mathematics curriculum (Grades 9-12)]. Ankara, Turkey: Author.

Ministry of National Education. (2013b). Ortaokul matematik (5, 6, 7 ve 8. sinfflar) dersi ögretim program [Middle school mathematics curriculum (Grades 5-8)] Ankara, Turkey: Author

Park, S., \& Oliver, J. S. (2008). Revisiting the conceptualization of pedagogical content knowledge (PCK): PCK as a conceptual tool to understand teachers as professionals. Research in Science Education, 38, 261-284.

Segall, A. (2004). Revisiting pedagogical content knowledge: the pedagogy of content/ the content of pedagogy. Teacher and Teacher Education, 20, 489-504.

Shulman, L. S. (1986). Those who understand: Knowledge growth in teaching. Educational Researcher, 15, 4-14.

Shulman, L. S. (1987). Knowledge and teaching: Foundations of the new reform. Harvard Educational Review, 57(1), 1-22.

Türnüklü, E. B., \& Yeşildere, S. (2007). Pedagogical content knowledge in mathematics: Pre-service primary school mathematics teachers' perspectives in Turkey. Issues in the Undergraduate Mathematics Preparation of School Teachers: The Journal, 1, 1-13. 
van Driel, J. H., \& Berry, A. (2010). Pedagogical content knowledge. In P. Peterson, E. Baker, \& B. McGaw (Eds.), International Encyclopedia of Education (pp. 656-661). Oxford, UK: Elsevier

van Driel, J. H., Verloop, N., \& de Vos, W. (1998). Developing science teachers' pedagogical content knowledge. Journal of Research in Science Teaching, 35, 673-695.

Yıldırım, A., \& Şimşek, H. (2008). Sosyal bilimlerde nitel araştırma yöntemleri [Qualitative research methods in the social sciences] (7th ed.). Ankara, Turkey: Seçkin Yayıncılık.

\section{Appendix}

The Studies Examined in the Research

1. Boz, N. (2004). Interactions between knowledge of variables and knowledge about teaching variables (Doctoral dissertation, University of Warwick, Coventry, UK.). Retrieved from http://ethos.bl.uk/OrderDetails.do?uin=uk.bl.ethos.409964

2. Türnüklü, B. E. (2005). Matematik öğretmen adaylarının pedagojik alan bilgileri ile matematiksel alan bilgileri arasındaki ilişki [The relationship between pre-service mathematics teachers' pedagogical content knowledge and knowledge of mathematical area]. Eurasian Journal of Educational Research, 21, 234-247.

3. Bütün, M., 2005. İlköğretim matematik ögretmenlerinin alan eğitimi bilgilerinin nitelikleri üzerine bir çalışma [The study of elemantary mathematics teachers' pedagogical content knowledge] (Master's thesis, Karadeniz Teknik Üniversitesi, Trabzon, Turkey). Retrieved from https://tez.yok.gov.tr/UlusalTezMerkezi/

4. Isıksal, M. (2006). A study on pre-service elementary mathematics teachers'subject matter knowledge and pedagogical content knowledge regarding the multiplication and division of fractions (Doctoral dissertation, Middle East Technical University, Ankara, Turkey). Retrieved from https://tez.yok.gov.tr/UlusalTezMerkezi/

5. Akkoç, H., Yeşildere, S., \& Özmantar, F. (2007). Prospective mathematics teachers' pedagogical content knowledge of definite integral: the problem of limit process. British Society of Research in Mathematics Learning (BSRLM), University of Northampton, UK.

6. Özmantar, F., Akkoç, H., \& Bingolbali, E. (2008, July). Voices in shaping the subjectivity of pedagogical content knowledge. Paper presented at the 32nd International Conference on the Psychology of Mathematics Education (PME32), Morelia, MEXICO.

7. Yüksel, G. (2008). Farklı içerik seviyelerindeki lise matematik ögretmen adaylarının ders planlarında gözlenen pedagojik içerik bilgisinin incelenmesi [Investigation of high school math pre-service teachers' pedagogical content knowledge as observed in their lesson plan at different content levels] (Master's thesis, Gazi University, Ankara). Retrieved from https://tez.yok.gov.tr/UlusalTezMerkezi/

8. Akkaya, E., Akkoç, H., Bingölbali, E., \& Özmantar, M. F. (2009, May). Matematik ögretmen adaylarına pedagojik alan bilgisi kazandırma amaçlı bir ders tasarımı ve ögretmen adaylarının gelişimlerine etkisi [A design course for pre-service mathematics teachers to gain pedagogical content knowledge and its effect on their development]. Paper presented at the First International Congress of Educational Research, Çanakkale, Turkey.

9. Pırasa, N. (2009). Sinıf öğretmeni adaylarının matematik ögretimiyle ilgili bilgilerinin değişim sürecinin incelemesi [Examination of the process of change in pre-service classroom teachers' knowledge related to teaching] (Doctoral dissertation, Karadeniz Technical University, Trabzon, Turkey). Retrieved from https://tez.yok.gov.tr/UlusalTezMerkezi/ 
10. Dönmez, G. (2009). Matematik öğretmen adaylarının limit ve süreklilik kavramlarına ilişkin pedagojik alan bilgilerinin değerlendirilmesi [Evaluation of mathematics pre-service teachers' pedagogical content knowledge related to the concepts of limit and continuity] (Master's thesis, Marmara University, İstanbul, Turkey). Retrieved from https://tez.yok.gov.tr/UlusalTezMerkezi/

11. Bukova-Güzel, E., Kula, S., Uğurel, I., \& Özgür, Z. (2010). Sufficiency of undergraduate education in developing mathematical pedagogical content knowledge: Student teachers' views. Procedia Social and Behavioral Sciences, 2(2), 2222-2226.

12. Bayazıt, İ., \& Aksoy, Y. (2010). Öğretmenlerin fonksiyon kavramı ve öğretimine ilişkin pedagojik görüşleri [Teachers' concept of function and their pedagogical related to teaching]. Gaziantep Üniversitesi Sosyal Bilimler Dergisi, 9(3), 697-723.

13. Bukova-Güzel E. (2010). An investigation of pre-service mathematics teachers' pedagogical content knowledge, using solid objects. Scientific Research and Essays, 5, 1872-1880.

14. Cankoy, O. (2010). Mathematics teachers' topic-specific pedagogical content knowledge in the context of teaching $\mathrm{a}^{0}, 0$ !, and a $\div 0$. Educational Sciences: Theory \& Practice, 10, 749-769.

15. Öner, D. (2010). Öğretmenin bilgisi özel bir bilgi midir? Öğretmek için gereken bilgiye kuramsal bir bakış [Is the teacher's knowledge special knowledge? An overview of the theoretical knowledge required for teaching]. Boğaziçi Üniversitesi Eğitim Dergisi, 27(2), 23-32.

16. Karagöz-Akar, G. (2010). Bir matematik öğretmeni ne bilmeli? Alan bilgisi ve alan eğitimi bilgisi arasındaki fark [What should a math teacher know? The difference between knowledge of area and knowledge of area education]. Boğaziçi Üniversitesi Eğitim Dergisi, 27(2), 33-47.

17. Yeşildere, S., \& Akkoç, H., 2010. Matematik Öğretmen Adaylarının Sayı Örüntülerine İlişkin Pedagojik Alan Bilgilerinin Konuya Özel Stratejiler Bağlamında İncelenmesi [Investigation of mathematics pre-service teachers' pedagogical content knowledge related to number patterns in the context of topic-specific strategies]. On Dokuz Mayls Üniversitesi Ĕ̈itim Fakültesi Dergisi, 29(1), 125-149.

18. Özmantar, M. F. (2010). Rethinking about the pedagogy for pedagogical content knowledge in the context of mathematics teaching. Eurasia Journal of Mathematics, Science \& Technology Education, 7(1), 15-27.

19. Karahasan, B. (2010). Preservice secondary mathematics teachers' pedagogical content knowledge of composite and inverse functions (Doctoral dissertation, Middle East Technical University, Ankara, Turkey). Retrieved from https://tez.yok.gov.tr/UlusalTezMerkezi/

20. Gökbulut, Y. (2010). Sınıf öğretmeni adaylarının geometrik cisimler konusundaki pedagojik alan bilgileri [Classroom pre-service teachers' pedagogical content knowledge of geometric objects] (Master's thesis, Gazi University, Ankara, Turkey). Retrieved from https://tez.yok.gov.tr/UlusalTezMerkezi/

21. Şandır, H. (2010). Matematik ögretmen ve ögretmen adaylarının tasarladıkları ve uyguladıkları modellemelere ait süreçlerin incelenmesi [Examination of the processes of simulations that math teachers and pre-service teachers' had designed and implemented] (Doctoral dissertation, Gazi University, Ankara, Turkey). Retrieved from https://tez.yok.gov.tr/UlusalTezMerkezi/

22. Durkaya, M., Aksu Z., Öçal M. F., Şenel Ö., Konyalığlu A. C., Hızarcı S., \& Kaplan A. (2011). Secondary school mathematics teachers' approaches to students' possible mistakes. Procedia Social and Behavioral Sciences, 15, 2569-2573.

23. Bütün, M. (2011). Matematik öğretmenlerinin alan eğitimi bilgi yapılarının incelenmesinde senaryo tipi mülakat sorularının kullanımı [The use of scenario-type interview questions in the study of mathematics teachers' pedagogical content knowledge structures]. Dicle Üniversitesi Ziya Gökalp Eğitim Fakültesi Dergisi, 16, 105-115. 
24. Toluk-Uçar, Z. (2011). Öğretmen adaylarının pedagojik içerik bilgisi: öğretimsel açıklamalar [Pdeagogical content knowledge of teachers: Instructional remarks]. Turkish Journal of Computer and Mathematics Education, 2(2), 87-102.

25. Uğurlu, R., \& Akkoç H. (2011). Matematik öğretmen adaylarının ölçme-değerlendirme bilgilerinin gelişiminin tamamlayıcı-şekillendirici ölçme-değerlendirme bağlamında incelenmesi [Examining the development of mathematics pre-service teachers' knowledge and development of measurement and evaluation in the context of measurement and evaluation of complementary styles]. Pamukkale Üniversitesi Eğitim Fakültesi Dergisi, 30(2), 155-167.

26. Kula, S. (2011). Matematik ögretmen adaylarının dörtlü bilgi modeli ile alan ve alan ögretim bilgilerinin incelenmesi: Limit örneği [Investigating mathematics pre-service teachers' knowledge of area through the model of four knowing and their knowledge of teaching area: the example of limit] (Master's thesis, Dokuz Eylül University, İzmir, Turkey). Retrieved from https://tez.yok.gov.tr/UlusalTezMerkezi/

27. Şimşek, N. (2011). Matematik öğretmen adaylarının çevre ve alan konularına ilişkin alan eğitimi bilgilerinin ögrenci zorlukları bağlamında incelenmesi [Examining mathematics pre-service teachers' knowledge of teaching topics related to perimeter and area in the context of student difficulties] (Master's thesis, Gazi University, Ankara, Turkey). Retrieved from https://tez.yok.gov.tr/UlusalTezMerkezi/

28. Yeşildere, S., \& Akkoç, H. (2010). Investigating the development of prospective mathematics teachers' pedagogical content knowledge of generalising number patterns through school practicum. Journal of Mathematics Teacher Education, 15, 207-226.

29. Gökkurt, B., Şahin, Ö., \& Soylu, Y. (2012). Matematik öğretmenlerinin matematiksel alan bilgileri ile pedagojik alan bilgileri arasındaki ilişkinin incelenmesi [Examination of the relation between mathematics teachers' knowledge of mathematics and pedagogical content knowledge]. The Journal of Academic Social Science Studies, 5(8), 997-1012.

30. Baki, M. (2012). Sınıf ögretmeni adaylarının matematiği ögretme bilgilerinin gelişiminin incelenmesi: bir ders imecesi (lesson study) çalışması [Examining the development of classroom pre-service teachers' knowledge of teaching mathematics: Study of the collective work of a lesson] (Doctoral dissertation, Karadeniz Technical University, Trabzon, Turkey). Retrieved from https://tez.yok.gov.tr/UlusalTezMerkezi/

31. Bütün, M. (2012). İlkögrretim matematik ögretmeni adaylarının uygulanan zenginleştirilmiş program sürecinde matematiği ögretme bilgilerinin gelişimi [Development of primary school pre-service teachers' knowledge of teaching mathematics in the application process of the enrichment program] (Doctoral dissertation, Karadeniz Technical University,, Trabzon, Turkey). Retrieved from https://tez.yok.gov.tr/UlusalTezMerkezi/

32. Kubar, A. (2012). Pre-service elementary mathematics teachers' knowledge about definitions of integers and their knowledge about elementary students' possible misconceptions and errors in describing integers (Master's thesis, Middle East Technical University, Ankara, Turkey). Retrieved from https://tez.yok.gov.tr/UlusalTezMerkezi/

33. Sezer, E. (2012). Matematik öğretimi dersi kapsamında kullanılan yazma etkinliklerinin sinıf ögretmeni adaylarının kesirler konusuna ilişkin pedagojik alan bilgilerine etkisinin incelenmesi [Examining the effects of writing activities used in the scope of teaching mathematics on preservice teachers' pedagogical content knowledge] (Master's thesis, Hacettepe University, Ankara, Turkey). Retrieved from https://tez.yok.gov.tr/UlusalTezMerkezi/

34. Baki, M. (2013). Sınıf öğretmeni adaylarının bölme işlemi ile ilgili matematiksel bilgileri ve öğretimsel açıklamaları [Classroom pre-service teachers' knowledge of the process of division and their instructional descriptions]. Eğitim ve Bilim, 38(167), 300-311. 
35. Şahin, Ö., Gökkurt, B., Başıbüyük, K., Erdem, E., Nergiz, T., \& Soylu, Y.(2013). Matematik ve sınıf öğretmeni adaylarının pedagojik alan bilgilerinin karşılaştırılması [Comparison of mathematics and classroom pre-service teachers' pedagogical content knowledge]. The Journal of Academic Social Science Studies, 6(4), 693-713.

36. Hacı̈̈meroğlu, G. (2013). Sınıf öğretmeni adaylarının öğretim için matematiksel bilgisi: öğrencilerin toplama ve çıkarma işlemlerine ilişkin çözümlerinin analizi [Pre-service teachers knowledge of mathematics for teaching: Analysis of solutions related to students' addition and subtraction]. Eğitim ve Bilim, 38(168), 332-346.

37. Bukova-Güzel, E., Cantürk-Günhan B., Kula, S., Özgür, Z., \& Elçi, A. N. (2013). Scale development for pre-service mathematics teachers' perceptions related to their pedagogical content knowledge. South African Journal of Education, 33(2), 1-21.

38. Tanışl1, D. (2013). İlköğretim matematik öğretmeni adaylarının pedagojik alan bilgisi bağlamında sorgulama becerileri ve öğrenci bilgileri [Questioning skills and student knowledge in the context of primary school mathematics pre-service teachers' pedagogical content knowledge]. Eğitim ve Bilim, 38(169), 80-95.

39. Esen, Y.(2013). Development of a test for assessing teachers' mathematical content knowledge for teaching geometric measurement at elementary grade level (Doctoral dissertation, Middle East Technical University, Ankara, Turkey). Retrieved from https://tez.yok.gov.tr/UlusalTezMerkezi/

40. Mercimek, O. (2013). Assessment of preservice mathematics teachers' knowledge for teaching statistics (Doctoral dissertation, Middle East Technical University, Ankara, Turkey). Retrieved from https://tez.yok.gov.tr/UlusalTezMerkezi/

41. Şahin, Ö., Erdem, E., Başıbüyük, K., Gökkurt, B., \& Soylu, Y. (2014). Ortaokul matematik öğretmenlerinin sayılarla ilgili pedagojik alan bilgilerinin gelişsiminin incelenmesi [Developing middle school pre-service teachers' pedagogical content knowledge related to facts and figures]. Turkish Journal of Computer and Mathematics Education, 5(3), 207-230.

42. Güler, M. (2014). Öğretmen adaylarının matematik ögretme bilgilerinin incelenmesi: cebir örneği [Investigation of pre-service teachers knowledge of mathematics teaching: The example of algebra] (Master's thesis, Karadeniz Technical University, Trabzon, Turkey). Retrieved from https://tez.yok.gov.tr/UlusalTezMerkezi/

43. Altaylı, D., Konyalığlu, A. C., Cihan, A., Hızarcı, S., \& Kaplan, A. (2014). İlköğretim matematik öğretmen adaylarının üç boyutlu cisimlere ilişkin pedagojik alan bilgilerinin incelenmesi [Investigation of pre-service math teachers' pedagogic knowledge of threedimensional objects]. Middle Eastern \& African Journal of Educational Research, 10, 4-24.

44. Aksu, Z., \& Konyalığlu, A. C. (2014). Sınıf öğretmen adaylarının kesirler konusundaki pedagojik alan bilgileri [Class pre-service teachers' pedagogic knowledge of fractions]. Kastamonu Üniversitesi Kastamonu Eğitim Dergisi, 23(2), 723-738.

45. Akkaş, E. N. (2014). Ortaokul 5. ve 7. sinıf matematik ögretmenlerinin geometri öğretim süreçlerinin ve geometrik- pedagojik alan bilgilerinin incelenmesi [Examination of 5 th and 7 th grade middle-school teachers' pedagogic knowledge of geometry and geometric processes] (Doctoral dissertation, Dokuz Eylül University, İzmir, Turkey). Retrieved from https://tez.yok. gov.tr/UlusalTezMerkezi/

46. Özaltun, A. (2014). Matematik öğretmelerinin mesleki gelişimleri: öğrenci düşüncesi bilgisinin ögretime yansimast [The professional development of teaching mathematics: Academic reflection on knowledge of student thinking] (Master's thesis, Dokuz Eylül University, İzmir, Turkey). Retrieved from https://tez.yok.gov.tr/UlusalTezMerkezi/ 
47. Aydın, S. (2014). İlkögrretim matematik ögretmeni adaylarının ögretme bilgilerinin, inanıslarının ve ögrenme firsatlarının üniversiteler ve TEDS-M sonuçlarına göre karşılaş̧tırılması [A comparison of elementary mathematics pre-service teachers' teaching knowledge, beliefs, and learning opportunities according to universities and TEDS-M results] (Doctoral dissertation, Karadeniz Technical University, Trabzon, Turkey). Retrieved from https://tez.yok.gov.tr/UlusalTezMerkezi/

48. Tekin-Sitrava, R. (2014). An investigation into middle school mathematics teacher' subject matter knowledge and pedagogical content knowledge regarding the volume of $3 D$ solids (Doctoral dissertation, Middle East Technical University, Ankara, Turkey). Retrieved from https://tez.yok.gov.tr/UlusalTezMerkezi/

49. Kula, S., \& Bukova-Güzel, E. (2014). Matematik ve matematik öğretimi bilgisi ışığında dörtlü bilgi modelindeki beklenmeyen olaylar bilgisi [Knowledge of unexpected events in the four-knowledge model in light of knowledge of mathematics and mathematics teaching]. Turkish Journal of Computer and Mathematics Education, 5(1), 89-107.

50. Şahin, Ö., Gökkurt, B., \& Soylu, Y. (2015). Examining pre-service mathematics teachers' pedagogical content knowledge on fractions in terms of students' mistakes. International Journal of Mathematical Education in Science and Technology, 1-21. http://dx.doi.org/10 .1080/0020739X.2015.1092178

51. Didiş, G. M., Erbaş, A. K., Çetinkaya, B., Çakıroğlu, E., \& Alacacı, C. (2015). Öğrenci çalışmalarını incelemenin öğrenci düşünme şekillerini anlamadaki rolü ile ilgili matematik öğretmen adaylarının düşünceleri [Opinions of mathematics pre-service teachers related to the role of examining student performance in understanding students' style of thinking]. Turkish Journal of Computer and Mathematics Education, 6(2), 139-162.

52. Gökkurt, B., Şahin, Ö., Soylu, Y., \& Doğan, Y. (2015). Öğretmen adaylarının geometrik cisimler konusuna ilişkin öğrenci hatalarına yönelik pedagojik alan bilgileri [Teacher candidates' pedagogic knowledge of student misconceptions related to the subject of geometric objects]. Illkögretim Online, 14(1), 55-71.

53. Eroğlu, D., \& Tanışlı, D. (2015). Ortaokul matematik öğretmenlerinin temsil kullanımına ilişkin öğrenci ve öğretim stratejileri bilgileri [Middle-school mathematics teachers' knowledge of students on the use of representations and knowledge of education strategies]. Necatibey Ĕgitim Fakültesi Elektronik Fen ve Matematik Eğitimi Dergisi, 9(1), 275-307.

54. Çıkrıkçı, F. H. (2015). Ortaokul matematik öğretmen adaylarının cebir öğrenme alanına ilişkin alan ve pedagojik alan bilgilerinin incelenmesi [Examination of middle school mathematics teacher candidates' pedagogical content knowledge and knowledge of fields related to teaching algebra] (Master's thesis, Dokuz Eylül University, İzmir, Turkey). Retrieved from https://tez.yok.gov.tr/UlusalTezMerkezi/

55. Köklü, O. (2008). Teachers' content knowledge in teaching slope of a line (Master's thesis, Boğaziçi University, İstanbul, Turkey). Retrieved from https://tez.yok.gov.tr/UlusalTezMerkezi/

56. Gökkurt, B., Şahin, Ö., Soylu, Y., \& Soylu, C. (2013). Examining pre-service teachers’ pedagogical content knowledge on fractions in terms of students' errors. International Online Journal of Educational Sciences, 5(3), 719-735. 